\title{
Biochemical and molecular characterisation of the bacterial endophytes from native sugarcane varieties of Himalayan region
}

\author{
Digar Singh • Anita Sharma • Gurvinder Kaur Saini
}

Received: 18 June 2012/ Accepted: 10 August 2012/Published online: 4 September 2012

(c) The Author(s) 2012. This article is published with open access at Springerlink.com

\begin{abstract}
Seven endophytic bacterial isolates were finally recovered from native sugarcane varieties at hilly areas namely Berinag, Champawat and Didihat of Uttarakhand state in northern Himalayan region. New isolates and two standard cultures-Azospirillum brasilense and Gluconacetobacter diazotrophicus, were evaluated for their morphological, biochemical and molecular characteristics. Morphologically all were rod shaped, Gram-negative bacteria. Their plant growth promotory properties were also assessed which proved isolates $\mathrm{RtBn}$ and $\mathrm{StBn}$ as IAA producing. Except isolate $\mathrm{StBn}$, all were phosphate solubilising and except RtBn all produced siderophores. Molecular characterisation of the isolates was performed using amplified 16S r-DNA restriction analysis. Similarity index in unweighted pair group method with arithmetic mean programme clustered the isolates according to their geographical distribution. Native isolates showed insignificant similarity with South American strains used as standards. nifH amplification was observed with all the isolates used in the study which again establish them as potential $\mathrm{N}$-fixers.
\end{abstract}

Keywords Endophytes - Gluconacetobacter - Isolation · Biochemical · Molecular characterisation

D. Singh · G. K. Saini $(\bowtie)$

Department of Biotechnology, Indian Institute of Technology

Guwahati, Guwahati 781039, Assam, India

e-mail: gurvinder@iitg.ernet.in

\section{A. Sharma}

Department of Microbiology, G.B. Pant University of Agriculture and Technology, Pantnagar 263145, Uttaranchal, India

\section{Introduction}

Indian green revolution started in mid 1960s which enabled the food autonomy in country. However, excessive use of inorganic fertilizers and pesticides changed the traditional cultivation practices. The situation has become so alarming that now the role of microorganisms in development of sustainable agriculture is being realised. In order to increase the agricultural production, there has been a tendency to adopt high application rate of fertilizer and irrigation water, often together (Hussain and Jaloud 1995). Crop plants are able to utilise about $50 \%$ of the applied nitrogen fertilizer while $25 \%$ is lost through leaching, volatilisation, denitrification, etc. This causes not only an annual economic loss of three billion US\$ but also pollutes the environment (Saravanan et al. 2008). On the other hand, biological nitrogen fixation (BNF) is a microbiological process which converts atmospheric nitrogen into the readily accessible form to plants.

Research to improve crop responses has emphasised the study of nitrogen-fixing bacteria indigenous to rhizosphere, but little is known about the non-rhizospheric nitrogenfixing bacterial population associated with the plants. These include Cyanobacteria, Azotobacter, Acetobacter, Azospirillum, Azolla-Anabaena symbiosis, Frankia-nonlegume nodulation, Bacillus, Burkholderia, Pseudomonas, Rhizobium, etc. (Poblet et al. 2000; Muthukumarasamy et al. 2000; Mendes et al. 2007). Among this group, Acetobacter diazotrophicus, a sugarcane endophyte has been reported and studied worldwide (James and Olivares 1998). The presence of A. diazotrophicus has also been reported in rice (Flores Encarnacion et al. 1999) and wheat (Kennedy et al. 1997). Nitrogen-fixing microbes inhabit varieties of tissues and organelles in plants such as seeds, roots, stems and leaves (Johri 2006). Plants are benefited extensively by 
harbouring these endophytic microbes and confer enhanced resistance against pathogens (Compant et al. 2005; Clay and Schardl 2002; Hoflich 2000; Arnold et al. 2003) by introducing antibiotics and siderophores (Ezra et al. 2004; Tortora et al. 2011).

These endophytes from different environmental, geographical and physiological conditions may have resulted in allopatric polymorphism. The present study aims to characterise morphological, biochemical and plant growth promotory (PGP ) properties of the isolates. The ribosomal RNA genes of bacteria, especially those for $16 \mathrm{~S}$ and $23 \mathrm{~S}-$ rRNA, are excellent molecular markers for phylogenetic studies because of their functional constancy and their ubiquitous distribution (Amann 1995). Molecular phylogeny of the diazotrophic spp. using ARDRA technique subjects the amplified $16 \mathrm{~S}$ rDNA gene to restriction digestion and thus is termed as the 'amplified rDNA restriction analyses'. Hence, this work involved the isolation and characterisation of endophytic Acetobacter sp. from native sugarcane varieties at high altitudes of Uttarakhand (Himalayan region) and their relatedness with the standard strains.

\section{Materials and methods}

Collection of plant material for isolation of sugarcane endophytes

Sugarcane samples were collected from hilly areas of Uttarakhand state namely-Berinag, Didihat and Champawat, belonging to different altitudes in the Himalayan region. Endophytes were isolated from the root and shoot portions of the plant samples (Dobereiner et al. 1988). Finally, seven isolates were selected for further studies and assigned the respective codes (Table 1). Two standard bacterial cultures were also used, Azospirillum brasilense (MTCC-125) and Gluconacetobacter diazotrophicus (MTCC-1224).

Morphological characterisation of bacterial isolates

Bacterial isolates appeared on semi-solid LGIP medium $\left(\mathrm{K}_{2} \mathrm{HPO}_{4} 0.2 \mathrm{~g} / \mathrm{l}, \mathrm{KH}_{2} \mathrm{PO}_{4} 0.6 \mathrm{~g} / \mathrm{l}, \mathrm{MgSO}_{4} \cdot 7 \mathrm{H}_{2} \mathrm{O} 0.2 \mathrm{~g} / \mathrm{l}\right.$, $\mathrm{CaCl}_{2} 0.2 \mathrm{~g} / \mathrm{l}, \mathrm{Na}_{2} \mathrm{MoO}_{4} 0.002 \mathrm{~g} / \mathrm{l}, \mathrm{FeCl}_{3} 0.01 \mathrm{~g} / \mathrm{l}$, bromothymol blue $0.5 \%$ in $0.2 \mathrm{M} \mathrm{KOH}$, agar $2 \%$, sucrose $100 \mathrm{~g} / \mathrm{l}$ at $\mathrm{pH} 5.5$ ) vials and plates showed typical light or

Table 1 Characteristic features of the different isolates

\begin{tabular}{|c|c|c|c|c|c|c|c|}
\hline Characteristics & $\mathrm{StBn}$ & RtBn & StDd & RtDd & $\mathrm{RtChI}$ & RtChII & $\mathrm{StCh}$ \\
\hline Place of isolation & Berinag & Berinag & Didihat & Didihat & Champawat & Champawat & Champawat \\
\hline Plant portion & Stem & Root & Stem & Root & Root & Root & Stem \\
\hline \multicolumn{8}{|l|}{ Colony morphology } \\
\hline Configuration & Round & Round & Oval & Oval & Round & Round & Round \\
\hline Margins & Wavy & Wavy & Smooth & Smooth & Smooth & Smooth & Smooth \\
\hline Elevation & Convex & Convex & Convex & Convex & Convex & Convex & Convex \\
\hline Shape & Circular & Circular & Circular & Circular & Circular & Circular & Circular \\
\hline Pigmentation & White & Creamy & Light creamy & Creamy & Creamy & Creamy & Creamy \\
\hline \multicolumn{8}{|l|}{ Cell morphology } \\
\hline Gram's reaction & - & - & - & - & - & - & - \\
\hline Shape & Long rods & Long rods & Short rods & Short rods & Short rods & Long rods & Long rods \\
\hline Arrangement & Single & Single & Single & Single & Single & Paired & Single \\
\hline \multicolumn{8}{|l|}{ PGPR properties } \\
\hline Phosphorous-solubilisation & - & + & + & + & + & + & + \\
\hline Siderophore-production & + & - & + & + & + & + & + \\
\hline IAA-production & $+(7.2 \mu \mathrm{g} / \mathrm{ml})$ & $+(8.92 \mu \mathrm{g} / \mathrm{ml})$ & - & - & - & - & - \\
\hline \multicolumn{8}{|l|}{ Biochemical characteristics } \\
\hline $\mathrm{H}_{2} \mathrm{~S}$ production & + & + & + & + & + & + & + \\
\hline Gelatin hydrolysis & - & - & - & - & - & - & - \\
\hline Casein hydrolysis & - & - & - & - & - & + & - \\
\hline Starch hydrolysis & - & - & - & - & - & - & - \\
\hline Catalase activity & + & + & + & - & - & + & + \\
\hline Denitrification test & - & - & - & + & + & + & - \\
\hline Cellulase activity & - & - & - & - & - & - & - \\
\hline
\end{tabular}

(Positive test $^{+}$, Negative test ${ }^{-}$) 
heavy orange-yellow surface pellicle on the medium. Gram staining and morphological studies were also performed on the isolates (Holt et al. 1994).

Functional characterisation of the bacterial isolates

\section{Antibiotic sensitivity test}

One millilitre of actively growing bacterial cultures was pour plated in nutrient agar plates. Antibiotic discs (Himedia) of Ceftriaxone (Cf30; 30 $\mu \mathrm{g} / \mathrm{disc})$, Clotrimazole (Cl30; $30 \mu \mathrm{g} / \mathrm{disc}$ ), Tetracyline (T30; $30 \mu \mathrm{g} / \mathrm{disc})$, Metronidazole (Mt3; $3 \mu \mathrm{g} / \mathrm{disc}$ ) and Amoxyclav (Ac5; $5 \mu \mathrm{g} / \mathrm{disc}$ ), were placed at four corners of solidified plates. Plates were incubated for 2-3 days at $30 \pm 2{ }^{\circ} \mathrm{C}$. Inhibition zones appeared after the incubation was noted for individual organisms and antibiotic(s).

\section{Carbohydrate utilisation studies}

Carbohydrate kits (KB009 Hicarbohydrate kit, Himedia) containing 35 different sugars in three sets (A, B and C) were inoculated with bacterial cultures separately and incubated at $30 \pm 2{ }^{\circ} \mathrm{C}$ for $48 \mathrm{~h}$. After incubation, results were observed and compared according to colour chart of the kit. Carbon source utilisation profiling was used for establishing phylogenetic relationship between isolates and the standard by unweighted pair group method with arithmetic mean (UPGMA), sub programme of online software http://genomes. urv.cat/UPGMA/index.php?entrada=Example2 (Garcia-Vallve et al. 1999).

Plant growth promotory studies

\section{Phosphorous solubilisation}

Actively growing bacterial culture(s) were spot inoculated on Pikovaskya medium agar plates with composition; (Yeast extract $0.5 \mathrm{~g} / \mathrm{l}$, Dextrose $10 \mathrm{~g} / \mathrm{l},\left(\mathrm{NH}_{4}\right)_{2} \mathrm{SO} 40.5 \mathrm{~g} / \mathrm{l}$, $\mathrm{Ca}_{3}\left(\mathrm{PO}_{4}\right)_{2} 5 \mathrm{~g} / \mathrm{l}, \mathrm{KCl} 0.2 \mathrm{~g} / \mathrm{l}, \mathrm{MgSO}_{4} 0.1 \mathrm{~g} / \mathrm{l}, \mathrm{MnSO}_{4}$ $0.0001 \mathrm{~g} / \mathrm{l}, \mathrm{FeSO}_{4} 0.001 \mathrm{~g} / \mathrm{l}$, Agar $15 \mathrm{~g} / \mathrm{l}$ at $\mathrm{pH}$ 7.0), and incubated at $30^{\circ} \mathrm{C}$ for 3 days. Positive isolates developed transparent zone(s) against white opaque background.

\section{Siderophore production (qualitative assay)}

Bacterial culture(s) were spot inoculated on chrome-azurol sulphonate (CAS, Sigma-Aldrich, USA) agar plates (Schwyn and Neilands 1987). The medium was poured on sterile Petri dishes; then spot inoculated with $10 \mu \mathrm{l}$ of each of the bacterial isolate at $\log$ phase and incubated for $3-5$ days at $30^{\circ} \mathrm{C}$. Positive results were indicated by the formation of an orange-yellow zone around the colonies.
Quantification of IAA production

Tubes of YPM (Yeast-Peptone-Mannitol) broth $5 \mathrm{ml}$ with tryptophan $(100 \mu \mathrm{g} / \mathrm{ml})$ and its control were inoculated and overnight incubated at $30{ }^{\circ} \mathrm{C}$ and $100 \mathrm{rpm}$ shaking. After incubation, cultures were centrifuged at $8,000 \mathrm{rpm}$ for $10 \mathrm{~min}$. Two millilitres of freshly prepared Salkowski reagent $\left(1 \mathrm{ml}\right.$ of $0.4 \mathrm{M} \mathrm{FeCl}_{3}$ in $50 \mathrm{ml}$ of $35 \%$ Perchloric acid) was added to $1 \mathrm{ml}$ of culture supernatant. The reaction mixture was incubated at $30{ }^{\circ} \mathrm{C}$ for $25 \mathrm{~min}$. Development of pink colour indicates the production of IAA.

\section{Biochemical characterisation}

\section{Cellulase activity}

Freshly growing bacterial culture(s) were spot inoculated on nutrient agar plates supplemented with $0.2 \%$ carboxy methyl cellulose (CMC), plates were incubated at $30{ }^{\circ} \mathrm{C}$ for 3-5 days and were overlaid with Congo-red $(1 \mu \mathrm{g} / \mathrm{ml})$ solution for $15 \mathrm{~min}$. After washing the plate surface with $1 \mathrm{M} \mathrm{NaCl}$, clear zone around colony indicates cellulase production.

\section{Gelatin hydrolysis}

Nutrient gelatin medium was inoculated with a loopful of actively growing bacterial culture and incubated for 3 days at $30^{\circ} \mathrm{C}$. Control tubes solidified when placed in ice whereas medium in inoculated tubes remained unsolidified, showing positive gelatin hydrolysis test.

\section{Starch hydrolysis}

Nutrient agar plates supplemented with $0.3 \%$ soluble starch were inoculated with actively growing bacterial culture(s) aseptically and incubated for 3 days at $30^{\circ} \mathrm{C}$. When flooded with Gram's iodine, a clear yellow zone around the inoculation spots indicates starch hydrolysis.

\section{Casein hydrolysis}

Skim milk agar (Skim milk powder $100 \mathrm{~g} / \mathrm{l}$, agar $15 \mathrm{~g} / \mathrm{l}$ ) plates were spot inoculated with actively growing culture(s) aseptically and incubated for 3 days at $30{ }^{\circ} \mathrm{C}$. Clear zones around the inoculation spots indicate casein hydrolysis.

\section{Catalase activity}

Yeast extract tryptone broth tubes, inoculated with actively growing bacterial culture(s) were incubated for 3 days at $30{ }^{\circ} \mathrm{C}$. Catalase activity was observed by adding few drops 
of $3 \% \mathrm{H}_{2} \mathrm{O}_{2}$ to the broth cultures, kept on the glass slides. Formation of oxygen bubbles confirms the positive result.

\section{Denitrification test}

Nitrate broth with inverted Durham tube were inoculated with actively growing culture(s), and incubated for 2-3 days at $30{ }^{\circ} \mathrm{C}$ for the observation of gas production.

\section{Production of $\mathrm{H}_{2} \mathrm{~S}$}

SIM agar [Peptone $30 \mathrm{~g} / \mathrm{l}$, Beef extract $3 \mathrm{~g} / \mathrm{l}$, ferrous ammonium sulphate $0.20 \mathrm{~g} / \mathrm{l}$, sodiumthiosulphate $0.025 \mathrm{~g} /$ 1, agar $3 \mathrm{~g} / 1$ (pH 6.0)] stabs were inoculated with actively growing culture(s). Blackening along the line of inoculation shows a positive test after $3-5$ days at $30{ }^{\circ} \mathrm{C}$.

Molecular characterisation of bacterial endophytes

\section{$16 S$ rDNA amplification of genomic DNA}

16S rDNA amplification from extracted DNA was performed using universal eubacterial primers, $\mathrm{F}$ primer 5'-AGAGTTTGATCCTGGCTCAG-3' (Escherichia coli bases 8-27) and R primer 5'-TACCTTGTTTTACGACTT $-3^{\prime}$ (E. coli bases 1507-1492). PCR reaction mixture $(50 \mu \mathrm{l})$, made with $5 \mu \mathrm{l}$ of genomic DNA, $5 \mu \mathrm{l}$ of PCR buffer $(10 \times), 3 \mu \mathrm{l}$ of $\mathrm{MgCl}_{2}, 1.25 \mu \mathrm{l}$ of dNTP mixture, $1.25 \mu \mathrm{l}$ of forward and reverse primers each and $0.2 \mu \mathrm{l}$ of Taq DNA polymerase. PCR reaction was performed in a thermocycler (eppendorf) and programmed as follows: Initial denaturation at $94{ }^{\circ} \mathrm{C}$ for $7 \mathrm{~min}$, followed by 40 cycles of denaturation step at $94{ }^{\circ} \mathrm{C}$ for $1 \mathrm{~min}$, annealing at $54{ }^{\circ} \mathrm{C}$ for $1 \mathrm{~min}$, extension at $74{ }^{\circ} \mathrm{C}$ for $1 \mathrm{~min}$ and the final extension at $72{ }^{\circ} \mathrm{C}$ for $10 \mathrm{~min}$. PCR amplicon(s) were run on $1 \%$ agarose gel and visualised under UV gel documentation system (Gel Doc Mega-Biosystematica).

\section{ARDRA-Amplified $16 S$ rDNA restriction analysis of the amplicons}

16S rDNA amplicons were digested separately with four restriction enzymes in $25 \mu \mathrm{l}$ reaction volume containing, Amplicon $20 \mu \mathrm{l}$, Digestion buffer $2.5 \mu \mathrm{l}(10 \times)$, Enzyme $0.1 \mu \mathrm{l}$ and the rest being TDW (triple distilled water). Reaction mixtures containing $M s p$ I, Alu I, Hae III and $M n l$ II each were incubated at $37{ }^{\circ} \mathrm{C}$ for $3 \mathrm{~h}$.

\section{Phylogenetic analysis}

ARDRA profile of isolates was analysed on $2.5 \%$ agarose gel. The specific band pattern was scored with binary characters $(1=$ presence and $0=$ absence, of bands $)$ and the phylogenetic tree was constructed using the UPGMA, a sub programme of online software http://genomes.urv.cat/ UPGMA/index.php?entrada=Example2 (Garcia-Vallve et al. 1999). Cluster analysis of the isolates was done using similarity coefficient.

\section{nifH amplification}

nifH region of $360 \mathrm{bp}$ was amplified using degenerate primer sequences (Saikia and jain 2007). Pol F primerTGC GAY CCS AAR GCB GAC TC., Pol R primer- ATS GCC ATC ATY TCR CCG GA. PCR reaction in $50 \mu \mathrm{l}$ reaction volume was set with: $5 \mu \mathrm{l}$ of genomic DNA, $5 \mu \mathrm{l}$ of PCR buffer $(10 \times), 3 \mu \mathrm{l}$ of $\mathrm{MgCl}_{2}, 1.25 \mu \mathrm{l}$ of dNTP mixture, $0.5 \mu \mathrm{mol}$ of forward and reverse primers each and $0.2 \mu \mathrm{l}$ of Taq DNA polymerase. PCR reaction was performed in a thermocycler (eppendorf) and programmed as follows: Initial denaturation at $95{ }^{\circ} \mathrm{C}$ for $5 \mathrm{~min}$, followed by 35 cycles of denaturation at $94{ }^{\circ} \mathrm{C}$ for $1 \mathrm{~min}$, annealing at $56{ }^{\circ} \mathrm{C}$ for $1 \mathrm{~min}$, extension at $72{ }^{\circ} \mathrm{C}$ for $2 \mathrm{~min}$ (Chauhan 2008). PCR amplicon (s) were run on $1 \%$ agarose gel and visualised under UV gel documentation system (Gel Doc Mega-Biosystematica).

\section{Results and discussion}

Isolation of bacterial endophytes from sugarcane

Based on the reported growth characteristics of Gluconacetobacter spp. seven suspected bacterial endophytes from different sugarcane samples were recovered, purified and assigned the respective codes (Table 1). These were observed for their shape, size, pigmentation and margin along with the colony/cell morphology of individual isolates (Table 1). Characteristic yellow/orange pigmented pellicle of Acetobacter appeared after 10-14 days of incubation in LGIP-agar plates; however, it takes only 5-6 days in air tight vials indicating their higher nitrogenase activity under microaerophilic environment (Cavalcante and Dobereiner 1988). All the isolates were able to grow in semi-solid LGIP medium ( $\mathrm{pH}$ 5.5), indicating the necessity of acidic environment for these cultures (Baldani and Baldani 2005). Heavy or moderate mucous secretion was observed for all the isolates, which might help to maintain optimum $\mathrm{O}_{2}$ concentration without inhibiting nitrogenase activity and cell metabolism (Dong et al. 2002).

Functional characterisation of bacterial endophytes

All isolates were found to be insensitive to the antibiotics used, except StBn and RtBn (isolates from Berinag). Both 
of these were inhibited significantly by Tetracyline and Metronidazole whereas Amoxyclav inhibited StBn only. This shows a significant degree of geographical sympatry among the isolates.

\section{Carbon source utilisation profiling}

The assay produced response patterns that distinguished among widely disparate samples and among dissimilar sample types within larger categories. Differentiation of

Table 2 Carbohydrate utilisation pattern of endophytic bacterial isolates

\begin{tabular}{|c|c|c|c|c|}
\hline Carbohydrate & StBn & RtChII & StDd & G. diazotrophicus \\
\hline Lactose & - & + & + & - \\
\hline Xylose & - & + & + & + \\
\hline Maltose & - & + & - & - \\
\hline Fructose & - & + & - & - \\
\hline Dextrose & - & + & + & + \\
\hline Galactose & - & + & + & + \\
\hline Raffinose & - & + & - & - \\
\hline Trehalose & - & + & - & - \\
\hline Melibiose & - & + & - & - \\
\hline Sucrose & - & + & - & - \\
\hline L-Arabinose & - & + & + & + \\
\hline Mannose & + & + & + & + \\
\hline Inulin & - & - & - & - \\
\hline Sodium gluconate & - & - & - & - \\
\hline Glycerol & - & - & - & - \\
\hline Salicin & - & - & - & - \\
\hline Glucosamine & - & + & + & + \\
\hline Dulcitol & - & + & + & + \\
\hline Inositol & - & + & + & + \\
\hline Sorbitol & - & - & - & - \\
\hline Mannitol & - & + & - & - \\
\hline Adonitol & - & + & - & - \\
\hline$\alpha$-Methyl-D-glucoside & - & - & - & - \\
\hline Ribose & - & - & + & + \\
\hline Rhamnose & - & + & - & - \\
\hline Cellobiose & - & - & - & - \\
\hline Melezitose & - & - & - & - \\
\hline$\alpha$-Methyl-D-mannoside & - & - & - & - \\
\hline Xylitol & + & + & + & + \\
\hline $\begin{array}{l}\text { ONPG (O-nitrophenyl- } \beta \text { - } \\
\text { D-galactopyranoside) }\end{array}$ & - & + & + & + \\
\hline Esculin & - & + & + & + \\
\hline D-Arabinose & - & + & + & + \\
\hline Citrate & - & + & + & + \\
\hline Malonate & - & + & + & + \\
\hline Sorbose & - & - & - & - \\
\hline
\end{tabular}

(Positive test $^{+}$, Negative test ${ }^{-}$) samples from different habitats was a useful preliminary test of the assay (Table 2). Carbon source utilisation profiling showed a significant relatedness among the isolates (Table 3). This involved one isolate each, StBn from Berinag $(1,740 \mathrm{~m})$, StDd from Didihat $(1,725 \mathrm{~m})$ and RtChII from Champawat $(1,610 \mathrm{~m})$, which were compared with the standard G. diazotrophicus. UPGMA hierarchical clustering showed approximately $94 \%$ similarity between StDd and the standard strain (Fig. 1a). StDd exhibited $75 \%$ similarity with RtChII, irrespective of its geographical closeness with StBn. Hence it can be inferred that metabolic similarity between the root isolates is more assertive than its geographical similarity.

Plant growth promotory studies

\section{Phosphorous solubilisation}

Except StBn, all the isolates showed clear zones on Pikovaskya medium (Pedraza 2008), indicating positive test

Table 3 Similarity matrix for the endophytic bacterial isolates and their Jaccard coefficient values based upon the dendrogram generated for the carbon source utilisation profiling for the selected strains and the standard used

\begin{tabular}{lllll}
\hline \multicolumn{4}{l}{ Similarity matrix computed with Jaccard coefficient } \\
\hline & StBn & RtChII & StDd & G. diazotrophicus \\
\hline StBn & 1 & 0.04 & 0.05 & 0.05 \\
RtChII & & 1 & 0.60 & 0.56 \\
StDd & & & 1 & 0.93 \\
G. diazotrophicus & & & & 1 \\
\hline
\end{tabular}

A

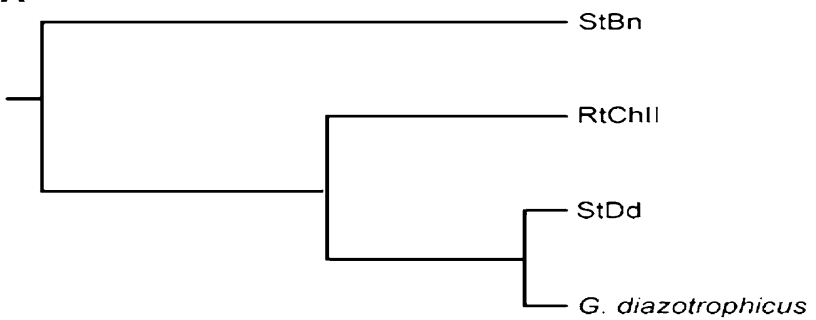

B

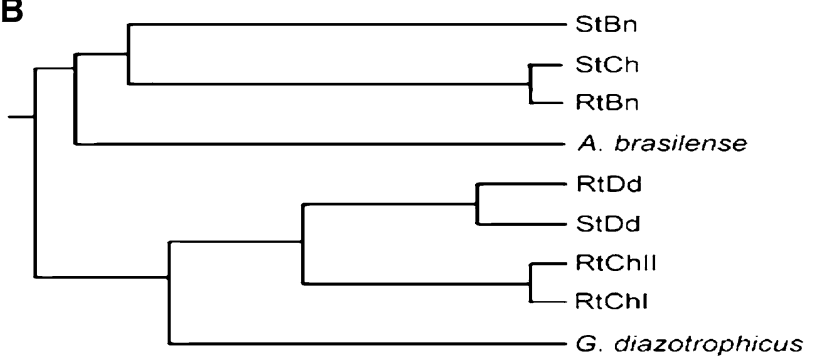

Fig. 1 a Dendrogram on the basis of carbohydrate utilisation pattern of endophytic bacterial isolates. b Combined phylogenetic tree based on ARDRA analysis using four restriction enzymes namely Alu I, $M s p$ I, Hae III and Mnl II 
for P-solubilisation (Table 1). In spite of the fact that soil usually contains high amounts of total phosphorous, its availability to plants is always scarce and thus a limiting factor.

\section{Siderophore production}

All the isolates produced siderophore on CAS-agar except RtBn (Table 1). Bacterial plant growth promotion (PGP)
Fig. 2 Restriction digestion of the $16 \mathrm{~S}$ rDNA amplicon, using enzymes. a Alu I, b Msp I, c $M n l$ II, d Hae III, e nifH amplification of the isolates and standards

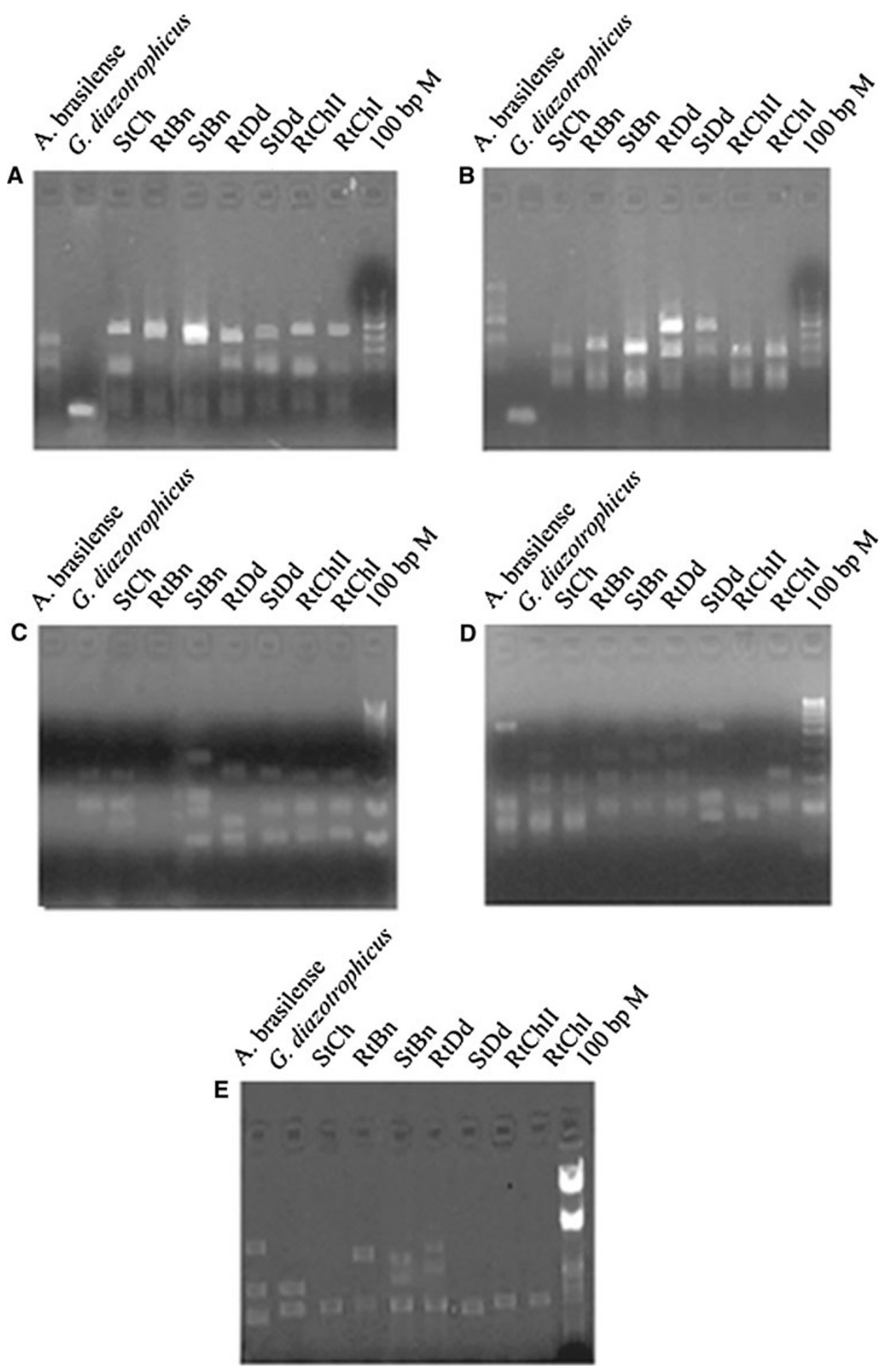


Table 4 Similarity matrix for the endophytic bacterial isolates and their Jaccard coefficient values based upon the dendrogram generated for the combined phylogenetic (ARDRA analysis) using four restriction enzymes namely Alu I, Msp I, Hae III and Mnl II

Similarity matrix computed with Jaccard coefficient

\begin{tabular}{|c|c|c|c|c|c|c|c|c|c|}
\hline & St.Bn. & Rt.Dd. & St.Dd. & Rt.Ch.II. & Rt.Ch.I & St.Ch. & Rt.Bn. & A. brasilense & G. diazotrophicus \\
\hline St.Bn. & 1 & 0.50 & 0.53 & 0.40 & 0.40 & 0.40 & 0.40 & 0.36 & 0.33 \\
\hline Rt.Dd. & & 1 & 0.90 & 0.69 & 0.69 & 0.25 & 0.25 & 0.45 & 0.41 \\
\hline St.Dd. & & & 1 & 0.61 & 0.61 & 0.27 & 0.27 & 0.50 & 0.33 \\
\hline Rt.Ch.II. & & & & 1 & 1 & 0.15 & 0.15 & 0.33 & 0.54 \\
\hline Rt.Ch.I & & & & & 1 & 0.15 & 0.15 & 0.33 & 0.54 \\
\hline St.Ch. & & & & & & 1 & 1 & 0.28 & 0.11 \\
\hline Rt.Bn. & & & & & & & 1 & 0.28 & 0.11 \\
\hline A. brasilense & & & & & & & & 1 & 0.10 \\
\hline G. diazotrophicus & & & & & & & & & 1 \\
\hline
\end{tabular}

can result from direct or indirect mechanisms, including siderophores production. They can improve vegetative growth by increasing plant nutrient availability through iron uptake and preventing the growth of soil borne pathogens due to iron limitation (Chaiharn et al. 2009; Miethke and Marahiel 2007).

\section{Indole acetic acid (IAA) production}

Out of seven isolates used in this study, only two isolates ( $\mathrm{StBn}$ and $\mathrm{RtBn}$ ) showed IAA production in the range of $7.2-8.9 \mu \mathrm{g} / \mathrm{ml}$ in the presence of tryptophan in YPM (Table 1). The YPM medium supplemented with tryptophan acts as precursor of IAA. PGP is accomplished by different mechanisms, such as, solubilisation of essential minerals, increased nutrient uptake, production of certain phytohormones like IAA, vitamins, enzymes and suppression of pathogens through siderophores or by bio-control agents.

\section{Biochemical characterisation}

All the isolates were $\mathrm{H}_{2} \mathrm{~S}$ producing and none of the isolates showed any response towards gelatin hydrolysis, starch hydrolysis and cellulase production (Table 1). Except RtChII, none of the isolates showed casein hydrolysis. Catalase activity was shown by all the isolates except RtChI and RtDd. The denitrification test was positive in case of RtDd, RtChI and RtChII. Hence these properties can be ascertained as an index of similarity or relatedness among the isolates and also signifies their agricultural importance.

Molecular characterisation of the isolates using ARDRA

ARDRA and subsequent UPGMA analysis offers a powerful tool for bacterial species identification. 16S rDNA amplicons of the isolates and standards were restriction digested individually with Alu I, Msp I, Hae III and Mnl II (Fig. 2ad). For any isolate, to belong to a given species, there must be at least $80-85 \%$ similarity based upon unweighted pair group method analysis. UPGMA cluster analysis resulted in two major clusters based upon the similarity index calculated using Jaccard coefficient (Table 4). Cluster I contained StBn with $40 \%$ similarity to $\mathrm{StCh}$ and $\mathrm{RtBn}$, whereas all these isolates showed significantly lesser $(<40 \%)$ similarity with $A$. brasilense. Cluster II included RtDd and StDd which were nearly $90 \%$ similar. Isolates RtChII and RtChI were identical with $100 \%$ similarity. Together these isolates were assigned the similarity in the range of 30-50\% to another standard used in the study, G. diazotrophicus (Fig. 1b). A $1,400 \mathrm{bp}$ amplicon from all the isolates confirmed their eubacterial nature. Together these isolates were less than $55 \%$ similar to both A. brasilense and G. diazotrophicus, which can be attributed to their different geographical pertaining. However, they showed significant homology varying from 55 to $70 \%$ as per their geographical kinship in terms of altitudes from sea level.

nifH amplification

nifH amplification was observed in all the recovered isolates, Azospirillum and Gluconacetobacter isolates with a common band of nearly $400 \mathrm{bp}$ (Fig. 2e). Multiple bands were observed in StBn, RtBn, StDd and standards. This may be due to the use of degenerate primers which amplify some of the non specific regions along with nifH gene (Ando et al. 2005). nifH, being the oldest existing functional genes in evolutionary history, was used for evaluating the relatedness among the isolates supplementary to ARDRA analysis. nifH PCR amplicons reflect genetic potential and thus also reflect genetic potential for nitrogen fixation in a particular environment. PCR using degenerate primers enables diverse group of microorganisms to be detected. Moreover, it also signifies the agricultural relevance of the isolates as potential nitrogen fixers. 
Acknowledgments We thank the University for providing us the facilities to complete the work.

Conflict of interest The authors declare that they have no conflict of interest.

Open Access This article is distributed under the terms of the Creative Commons Attribution License which permits any use, distribution, and reproduction in any medium, provided the original author(s) and the source are credited.

\section{References}

Amann RI (1995) Fluorescently labeled, ribosomal RNA targeted oligonucleotide probes in the study of microbial ecology. Mol Ecol 4:543-553

Ando S, Goto M, Meunchang S, Thongra-ar P, Fujiwara T, Hayashi $\mathrm{H}$, Yoneyama $\mathrm{T}$ (2005) Detection of nifH sequences in sugarcane (Sacchararum officinarum L.) and pineapple (Ananas comosus [L.] Merr). Soil Sci Plant Nutr 51:303-308

Arnold AE, Meffa LC, Kyollo D, Rojas EI, Maynard Z, Robbins N, Herre EA (2003) Fungal endophytes limit pathogen damage in a tropical tree. Proc Natl Acad Sci USA 100:15649-15654

Baldani JI, Baldani VLD (2005) History on the biological nitrogen fixation research in graminaceous plants: special emphasis on the Brazilian experience. Ann Brazil Acad Sci 77(3):549-579

Cavalcante VA, Dobereiner J (1988) New acid tolerant nitrogen fixing bacterium associated with sugarcane. Plant soil 108:23-31

Chaiharn M, Chunhaleuchanon S, Lumyong S (2009) Screening siderophore producing bacteria as potential biological control agent for fungal rice pathogens in Thailand. World J Microbiol Biotechnol 25(11):1919-1928

Chauhan H (2008) Biochemical and Molecular characterization of sugarcane endophytes and their potential in sugarcane growth promotion (Thesis G B P U A \& T)

Clay K, Schardl C (2002) Evolutionary origins and ecological consequences of endophyte symbiosis with grasses. Am Nat 160: $99-127$

Compant S, Reiter B, Sessitsch A, Nowak J, Clément C, Barka EA (2005) Endophytic colonization of Vitis vinifera L by plant growth-promoting bacterium Burkholderia sp. strain PsJN. Appl Environ Microbiol 71:1685-1693

Dobereiner J, Reis VM, Lazarini AC (1988) New $\mathrm{N}_{2}$ fixing bacteria in association with cereals and sugarcane. In: Bothe H, De Bruijn FJ, Newton WE (eds) Nitrogen: fixation hundred years after. Gustav Fischer, Stuttgart, pp 717-722

Dong Z, Zelmer CD, Canny MJ, McCully ME, Luit B, Pan B, Faustino RS, Pierce GN, Vessey JK (2002) Evidence for protection of nitrogenase from $\mathrm{O}_{2}$ by colony structure in the aerobic diazotroph Gluconacetobacter diazotrophicus. Microbiol 148:2293-2298

Ezra D, Hess WM, Strobel GA (2004) New endophytic isolates of Muscodor albus, a volatile-antibiotic-producing fungus. Microbiol 150:4023-4031

Flores Encarnacion M, Contreras Zentella M, Soto-Urzua L, Aguilar GR, Baca BE, Escamilla JE (1999) The respiratory system and diazotrophic activity of Acetobacter diazotrophicus pal 5. J Bacteriol 181:22. American Society for Microbiol 6987-6995

Garcia-Vallve S, Palau J, Romeu A (1999) Horizontal gene transfer in glycosyl hydrolases inferred from codon usage in Escherichia coli and Bacillus subtilis. Mol Biol Evol 9:1125-1134

Hoflich G (2000) Colonization and growth promotion of non-legumes by Rhizobium bacteria. Microbial Biosystems New Frontiers. In: Bell CR, Brylinsky M, Johnson-Green P (eds) Proceedings of the 8th International Symposium on Microbial Ecology. Atlantic Canada Society for Microbial Ecology, Halifax, pp 827-830

Holt JG, Krieg NR, Sneath PHA, Staley JT, Williams ST (1994) Bergey's manual of determinative bacteriology, 9th edn. The Williams and Wilkins Co, Baltimore

Hussain G, AI-Jaloud AA (1995) Effect of irrigation and nitrogen on water use efficiency of wheat in Saudi Arabia. Agric Water Manage 21:143-154

James EK, Olivares FL (1998) Infection and colonization of sugar cane and other graminaceous plants by endophytic diazotrophs. Crit Rev Plant Sci 17:77-119

Johri BN (2006) Endophytes to the rescue of plants. Curr Sci 90: $1315-1316$

Kennedy IR, Katupitiya S, Yu D, Deaker R, Gilchrist K, Pereg-Gerk L, Wood C (1997) Prospects for facilitated evolution of effective nitrogen fixing associations with cereals: comperative performance of Azospirillum brasilense Sp7-S with various free living diazotrophs in para-nodulated wheat. Plant Soil 106:169-178

Lee S, Flores-Encarnacion M, Contreras-Zentella M, Garcia-Flores L, Escamilla JE, Kennedy C (2004) Indole-3-acetic acid biosynthesis is deficient in Gluconacetobacter diazotrophicus strains with mutations in cytochrome $\mathrm{c}$ biogenesis genes. J Bacteriol 186:5384-5391

Mendes R, Aline A, LA Pizzirani-Kleiner Welington, Raaijmakerset JM (2007) Diversity of cultivated endophytic bacteria from sugarcane: genetic and biochemical characterization of Burkholderia cepacia complex isolates. Appl Environ Microbiol 73:7259-7267

Miethke M, Marahiel MA (2007) Siderophore-based iron acquisition and pathogen control. Mol Biol Rev 71(3):413-451

Muthukumarasamy R, Revathi G, Vadivelu M (2000) Antagonistic potential of $\mathrm{N}_{2}$-fixing Acetobacter diazotrophicus against Colletotrichum falcatum a causal organism of red-rot of sugarcane. Curt Sci 78:1063-1065

Pedraza RO (2008) Recent advances in nitrogen-fixing acetic acid bacteria. Int J Food Microbiol 125:25-35

Poblet MN, Guillamo JM, Mas A (2000) Identification of acetic acid bacteria by restriction fragment length polymorphism analysis of a PCR-amplified fragment of the gene coding for $16 \mathrm{~S} \mathrm{r}$ RNA. Lett Appl Microbiol 3:63-67

Saikia SP, Jain V (2007) Biological nitrogen fixation with nonlegumes: an achievable target or a dogma? Curr Sci 92:317-322

Saravanan VS, Madhaiyan M, Osborne J, Thangaraju M, Sa TM (2008) Ecological occurrence of Gluconacetobacter diazotrophicus and nitrogen-fixing Acetobacteraceae members: their possible role in plant growth promotion. Micro Ecol 55:130-140

Schwyn B, Neilands JB (1987) Universal chemical assay for the detection and determination of siderophores. Anal Biochem 160(1):47-56

Tortora ML, Diaz Ricci JC, Pedraza RO (2011) Azospirillum brasilense siderophores with antifungal activity against Colletotrichum acutatum. Arch Microbiol 193:275-286 